\title{
HBV Genotype B Is Associated With Better Response to Interferon Therapy in $\mathrm{HBeAg(+)} \mathrm{Chronic}$ Hepatitis Than Genotype C
}

\author{
Chun Tao Wai, Chi-Jen Chu, Munira Hussain, and Anna S. F. Lok
}

\begin{abstract}
Hepatitis B virus (HBV) genotype and precore/core promoter mutations have been implicated in spontaneous and interferon alfa (IFN- $\alpha$ )-related hepatitis $\mathrm{B}$ e antigen (HBeAg) seroconversion. We performed a retrospective analysis of a previously reported randomized controlled trial to determine the effects of $\mathrm{HBV}$ genotype and precore/core promoter mutations on IFN- $\alpha$ response in patients with $\mathrm{HBeAg}$-positive chronic hepatitis. Clinical data and stored sera from $109(95 \%)$ patients in the original trial were analyzed. Seventy-three patients received IFN- $\alpha$ and 34 received no treatment (controls). Almost all patients had HBV genotypes $B(38 \%)$ and $C(60 \%)$. Antiviral response was achieved in $39 \%$ and $17 \%$ of IFN- $\alpha$-treated patients $(P=.03)$ and in $10 \%$ and $8 \%$ of untreated controls $(P=.88)$ with HBV genotype $B$ and $C$, respectively. Multivariate analysis identified $H B V$ genotype $B$, elevated pretreatment alanine aminotransferase (ALT) levels, and low pretreatment HBVDNA levels but not IFN- $\alpha$ treatment as independent factors associated with antiviral response. Among the 66 patients with elevated pretreatment ALT level, antiviral response was achieved in $57 \%$ and $21 \%$ of IFN- $\alpha$-treated patients $(P=.019)$, and in $25 \%$ and $8 \%$ of untreated controls $(P=.45)$ with $\mathrm{HBV}$ genotype $B$ and $C$, respectively. Multivariate analysis showed that genotype $B$ and low pretreatment HBV-DNA levels were independent predictors of antiviral response. In conclusion, our data showed that $\mathrm{HBV}$ genotype $\mathrm{B}$ was associated with a higher rate of IFN-induced $\mathrm{HBeAg}$ clearance compared with genotype $\mathrm{C}$. Stratification for $\mathrm{HBV}$ genotypes should be considered in future clinical trials of antiviral therapy of chronic hepatitis B. (HEPATOLOGY 2002;36:1425-1430.)
\end{abstract}

I nterferon alfa (IFN- $\alpha$ ) and lamivudine are the 2 currently approved treatments for chronic hepatitis $B$ (CHB) in most countries. ${ }^{1}$ Both agents have limited long-term efficacy. IFN- $\alpha$ is associated with significant adverse effects, whereas long-term therapy with lamivudine may result in drug resistance. Thus, optimal patient selection for treatment is important. High pretreatment

Abbreviations: IFN- $\alpha$, inteferon alfa; $C H B$, chronic hepatitis $B ; A L T$, alanine aminotransferase; $H B V$, hepatitis $B$ virus; $H B e A g$, hepatitis $B$ e antigen; $O R$, odds ratio; $\mathrm{Cl}$, confidence interval.

From the Division of Gastroenterology, University of Michigan, Ann Arbor, MI. Received August 14, 2002; accepted September 12, 2002.

Supported by the Singapore HMDP Fellowship (C.T.W.) and a research fellowship from Taipei Veterans General Hospital and Research Foundation of Digestive Medicine, Republic of China (C.-J.C.). Supported by National Institutes of Health grants (NO1-DK-9-2323 and UO1-DK-57577) to A.S.F.L. Innogenetics Inc. provided the Inno-Lipa kits for HBV genotyping and detection of precore and core promoter variants.

Address reprint requests to: Anna S. F. Lok, M.D., Division of Gastroenterology, University of Michigan Medical Center, 3912 Taubman Center, Box 0362, Ann Arbor, Michigan 48109-0362. E-mail: aslok@umich.edu; fax: 734-936-7392.

Copyright $(2002$ by the American Association for the Study of Liver Diseases. 0270-9139/02/3606-0018\$35.0010

doi:10.1053/jhep.2002.37139 alanine aminotransferase (ALT) levels have been found to be the most important predictor of response to both IFN- $\alpha$ and lamivudine therapy. ${ }^{2-4}$ Low pretreatment serum hepatitis $B$ virus (HBV)-DNA levels also have been shown to be a predictor of response in many studies on IFN- $\alpha$ therapy. 2,3

Recently, HBV genotypes and precore and core promoter variants have been implicated in spontaneous hepatitis $\mathrm{B}$ e antigen ( $\mathrm{HBeAg}$ ) seroconversion as well as response to antiviral treatment. $\mathrm{HBV}$ can be classified into 7 genotypes (A to G). ${ }^{5}$ Genotype $A$ is more common in North America and northwestern Europe; genotypes B and $C$ are mainly found in Asia; genotype $D$ is predominant in the Mediterranean area, Middle East, and India; whereas the distribution of genotypes $E, F$, and $G$ is less well studied. ${ }^{6}$ Genotype $A$ was found to be associated with a higher rate of IFN- $\alpha$-induced $\mathrm{HBeAg}$ seroconversion than genotype $\mathrm{D}(37 \%$ vs. $6 \%, P=.03)$ in a study of 64 German patients with $\mathrm{HBeAg}$-positive CHB. ${ }^{7}$ Another study of 58 Taiwanese patients who received IFN- $\alpha$ treatment for $\mathrm{HBeAg}$-positive $\mathrm{CHB}$ found that patients with 
genotype $\mathrm{B}$ had a significantly higher rate of $\mathrm{HBeAg}$ loss compared with those with genotype $\mathrm{C}$ ( $41 \%$ vs. $15 \%, P=$ $.045) .{ }^{8}$ In the German study, a high number of mutations in the core promoter region and pretreatment $\mathrm{HBV}$ DNA level of less than $10 \mathrm{pg} / \mathrm{mL}$ also were associated with better response whereas in the Taiwan study, younger age was the only other factor associated with a higher rate of response. Both studies did not include an untreated group. Thus, it is not clear if IFN- $\alpha$ treatment had an incremental effect on $\mathrm{HBeAg}$ seroconversion when $\mathrm{HBV}$ genotype was controlled for.

The 2 most well-defined, naturally occurring HBV mutations are the point mutation in the precore region $\left(\mathrm{G}_{1896 \mathrm{G}} \mathrm{A}\right)$, creating a stop at codon 28 , and the dual mutation $A_{1762} \mathrm{~T} / \mathrm{G}_{1764} \mathrm{~A}$ at the basic core promoter region. ${ }^{9}$ Precore and core promoter mutations have been found to precede or emerge at the time of $\mathrm{HBeAg}$ seroconversion and to affect response to IFN- $\alpha$ therapy. In previous studies using direct sequencing, we showed that $\mathrm{HBeAg}$-positive patients with detectable precore and core promoter mutations were more likely to undergo spontaneous $\mathrm{HBeAg}$ clearance. ${ }^{10}$ Presence of precore mutations also was associated with a higher rate of response to IFN- $\alpha$ therapy ( $55 \%$ vs. $17 \%, P=.04$ ) as compared with those without precore mutations. ${ }^{11}$ However, other studies involving a smaller number of patients showed that the rate of IFN- $\alpha$-induced HBeAg seroconversion was not related to presence of precore stop codon mutations. ${ }^{12,13}$ Two studies, one involving German and another involving Chinese patients, found that presence of core promoter mutations was associated with a higher rate of IFN$\alpha$-induced $\mathrm{HBeAg}$ loss, whereas a third study from Germany failed to confirm this finding. ${ }^{7,14,15}$ These conflicting results may be caused by differences in patient characteristics, pretreatment ALT levels, and other virologic factors such as HBV genotypes. Almost all the earlier-mentioned studies included small numbers of patients and examined only a few potential predictors. Thus, further studies involving a larger number of patients are needed to identify independent predictors of response to IFN- $\alpha$ treatment. In addition, a parallel control group should be included to determine if IFN- $\alpha$ has any incremental benefit when baseline factors are controlled.

The effect of HBV genotype on response to nucleo$s(t)$ ide analogues is less clear because few studies have been reported to date. Of $43(33 \mathrm{HBeAg}$ positive and 10 $\mathrm{HBeAg}$ negative) $\mathrm{CHB}$ patients treated with lamivudine, those with ayw subtype had a trend toward better virologic and biochemical response than those with adw subtype. ${ }^{16}$ In another study on $31 \mathrm{HBeAg}$-positive $\mathrm{CHB}$ patients treated with lamivudine, no significant difference in $\mathrm{HBeAg}$ seroconversion was seen in patients with $\mathrm{HBV}$ genotype $\mathrm{B}$ or $\mathrm{C} .{ }^{17}$ Finally, a recent study of $1,032 \mathrm{CHB}$ (both $\mathrm{HBeAg}$ positive and negative) patients treated with adefovir dipivoxil showed no difference in viral load reduction after 48 weeks of treatment. ${ }^{18}$

We performed a retrospective analysis of a previously reported randomized controlled trial to determine the effects of HBV genotype, precore/core promoter mutations, as well as demographic factors and pretreatment ALT and HBV-DNA levels, on IFN- $\alpha$ response in Chinese patients with $\mathrm{HBeAg}$-positive $\mathrm{CHB}$.

\section{Patients and Methods}

Patients. Clinical data and stored sera from a placebocontrolled trial comparing IFN- $\alpha$ with and without prednisone versus placebo were studied. ${ }^{19}$ All patients were ethnic Chinese with the presence of hepatitis B surface antigen in serum for more than 6 months, and detectable $\mathrm{HBeAg}$ and serum HBV DNA (by direct spot hybridization). They were randomized to receive IFN- $\alpha$ with prednisone priming, IFN- $\alpha$ only, or no treatment (controls). Prednisone priming was given orally in daily doses of 45 , 30 , and $15 \mathrm{mg}$ each for 2 weeks, followed by a 2 -week rest before administration of IFN- $\alpha$. Interferon $\alpha-2 b$ (Intron A; Schering Plough, Kenilworth, NJ) was administered subcutaneously for 16 weeks in doses of 10 MU 3 times weekly. Liver biopsies were performed within 6 months of entry and again at month 12 . Antiviral response was defined as sustained clearance of serum HBV DNA by direct spot hybridization (lower limit of detection of $10 \mathrm{pg} / \mathrm{mL}$ ) and clearance of $\mathrm{HBeAg}$ at month 12 .

Serologic Testing. Hepatitis B serologic markers: hepatitis $B$ surface antigen, $\mathrm{HBeAg}$, and hepatitis $\mathrm{B}$ e antibody were tested by using commercially available enzyme-linked immunosorbent assay kits from Abbott Laboratories (North Chicago, IL).

HBV Genotype, Precore, and Core Promoter Mutations. Residual sera collected within 6 months before entry, which were stored at $-70^{\circ} \mathrm{C}$, were retrieved. $\mathrm{HBV}$ genotypes, precore $\left(G_{1896} A\right)$ and core promoter $\left(A_{1762} T\right.$ and $\left.G_{1764} A\right)$ mutations, were determined by line-probe assay (Inno-Lipa, Innogenetics Inc., Ghent, Belgium) as described previously. ${ }^{20}$ Comparison of the results of the line-probe assay and direct sequencing showed a concordance rate of $100 \%$ for HBV genotypes and greater than $95 \%$ for precore and core promoter mutations. ${ }^{21,22}$

Quantification of $\boldsymbol{H B V} \boldsymbol{D N A}$. Serum HBV-DNA level was quantified by a polymerase chain reaction assay with a lower limit of detection of 200 copies $/ \mathrm{mL}$ and a linearity range of $2 \times 10^{2}$ to $2 \times 10^{5}$ copies $/ \mathrm{mL}$ (Cobas Amplicor HBV Monitor, Roche Diagnostic Systems, 
Table 1. Demographic and Clinical Characteristics of Patients With or Without IFN Treatment

\begin{tabular}{|c|c|c|c|c|}
\hline & $\begin{array}{c}\text { Controls } \\
(n=34)\end{array}$ & $\begin{array}{c}\text { IFN- } \alpha+ \\
\text { Prednisone Priming } \\
\text { (n=36) }\end{array}$ & $\begin{array}{c}\text { IFN- } \alpha \text { No } \\
\text { Prednisone Priming } \\
(n=39)\end{array}$ & $\begin{array}{c}\text { IFN- } \alpha \\
\text { Combined } \\
(n=75)\end{array}$ \\
\hline Age, yr & $29 \pm 1$ & $30 \pm 1$ & $30 \pm 1$ & $30 \pm 1$ \\
\hline Sex: Male & $20(59 \%)$ & $24(67 \%)$ & $25(64 \%)$ & $49(66 \%)$ \\
\hline Pretreatment ALT level, U/L & $82 \pm 14$ & $103 \pm 15$ & $133 \pm 25$ & $118 \pm 15$ \\
\hline No. with elevated pretreatment ALT & $16(47 \%)$ & $25(69 \%)$ & $27(69 \%)$ & $52(69 \%)^{*}$ \\
\hline Pretreatment HBV DNA, $\log _{10}$ copies $/ \mathrm{mL}$ & $8.96 \pm 0.17$ & $8.56 \pm 0.18$ & $8.63 \pm 0.20$ & $8.59 \pm 0.14$ \\
\hline Pretreatment histology showing cirrhosis & $4(12 \%)$ & $3(8 \%)$ & $5(13 \%)$ & $8(11 \%)$ \\
\hline \multicolumn{5}{|l|}{ Genotype } \\
\hline B & $10(29 \%)$ & $17(47 \%)$ & $14(36 \%)$ & $31(41 \%)$ \\
\hline c & $24(71 \%)$ & $17(47 \%)$ & $25(64 \%)$ & $42(56 \%)$ \\
\hline $\mathrm{D}$ & 0 & $2(6 \%)$ & 0 & $2(3 \%)$ \\
\hline \multicolumn{5}{|l|}{ Precore mutation } \\
\hline $\mathrm{G}_{1896} \mathrm{~A}$ & $6(18 \%)$ & $16(44 \%)$ & $13(33 \%)$ & $29(39 \%) \dagger$ \\
\hline $\mathrm{G}_{1898 \mathrm{~A}} \mathrm{~A}$ & $1(3 \%)$ & 0 & 0 & 0 \\
\hline \multicolumn{5}{|l|}{ Core promoter mutation } \\
\hline $\mathrm{A}_{1762} \mathrm{~T}, \mathrm{G}_{1764 \mathrm{~A}} \mathrm{~A}$ & $12(35 \%)$ & $12(33 \%)$ & $15(39 \%)$ & $27(36 \%)$ \\
\hline Deletion & $2(6 \%)$ & $1(1 \%)$ & 0 & $1(1 \%)$ \\
\hline Single mutation $\left(A_{1762} T\right.$ or $\left.G_{1764} A\right)$ & 0 & $2(3 \%)$ & 0 & $2(3 \%)$ \\
\hline Antiviral response & $3(9 \%)$ & $11(31 \%)$ & $10(26 \%)$ & $21(28 \%) \ddagger$ \\
\hline
\end{tabular}

Comparisons between IFN-treated patients and controls:

${ }^{*} P=.033$.

$\dagger P=.038$

$\ddagger P=.064$

Inc., Pleasanton, CA). All samples were prediluted up to $10^{6}$ times. A 100,000-fold dilution was used for the initial testing of all samples as recommended by the manufacturer's manual. Retesting with either a higher or lower dilution was performed when results of the initial testing were out of the range of linearity of the assay.

Statistical Analysis. Results were expressed as mean \pm standard error of mean. Data were analyzed by using SPSS version 10.0 software package (SPSS Inc., Chicago, IL). Categoric variables were compared by the $\chi^{2}$ test. Continuous variables were compared by the Student's $t$ test. Multivariate analysis using stepwise logistic regression was performed to identify independent factors associated with IFN- $\alpha$ response. Results were considered statistically significant at $P<.05$.

\section{Results}

Patient Characteristics. Sera collected within 6 months before entry were successfully retrieved in 109 (95\%) of the original 115 patients. Among these 109 patients, $75(69 \%)$ were treated with IFN- $\alpha$ (36 with and 39 without prednisone priming), 12 (11\%) had cirrhosis on biopsy at entry, and $68(62 \%)$ had elevated ALT levels at baseline. Twenty-four (22\%) patients had an antiviral response. Demographic and clinical characteristics of IFN- $\alpha$-treated patients and controls are shown in Table 1. Because the rates of antiviral response in the 2 IFN- $\alpha$ treatment arms were similar, ${ }^{19}$ these 2 groups were combined in the subsequent analysis.
HBV Genotype, Precore, and Core Promoter Mutations. Forty-one (38\%) patients had genotype B, 66 (60\%) had genotype $\mathrm{C}$, and $2(2 \%)$ had genotype D. Thirty-five $(32 \%)$ patients had precore stop codon $\left(G_{1896} A\right)$ mutation. Of these, 23 had predominant widetype precore sequence, $6 \mathrm{had}$ an equal mix of wide-type and variant sequence, and 6 had predominant variant sequence. Thirty-nine $(36 \%)$ patients had dual core promoter $\left(A_{1762} T\right.$ and $\left.G_{1764} A\right)$ mutations. Of these, 8 had predominant wide-type core promoter sequence, 21 had an equal mix of wide-type and variant sequence, and 10 had predominant variant sequence.

Comparison Between Genotype B and C Patients. At entry, the 2 groups were comparable in age, and pretreatment HBV-DNA and ALT levels, but patients with genotype $B$ had a higher prevalence of precore and a lower prevalence of core promoter mutations (Table 2). The gender distribution in the 2 groups also was different, being equal among patients with genotype $\mathrm{B}$ and male predominant among patients with genotype $\mathrm{C}$.

Patients with HBV genotype $\mathrm{B}$ had a significantly higher rate of antiviral response to IFN- $\alpha, 39 \%$ versus $17 \%$ among patients with genotype $\mathrm{C}(P=.03)$ (Table 2).

Factors Associated With HBeAg Clearance. Factors associated with $\mathrm{HBeAg}$ clearance within 12 months of entry into the study among the 107 patients with genotype $B$ and $C$ were analyzed. $H B V$ genotype $B$, elevated pretreatment ALT level, low pretreatment HBV-DNA level, and treatment with IFN- $\alpha$ were found to be significant 
Table 2. Comparison of Patients With HBV Genotype B and C

\begin{tabular}{|c|c|c|c|}
\hline & $\begin{array}{l}\text { Genotype B } \\
(n=41)\end{array}$ & $\begin{array}{l}\text { Genotype C } \\
(\mathrm{n}=\mathbf{6 6})\end{array}$ & $\boldsymbol{P}$ \\
\hline Age, yr & $30 \pm 1$ & $29 \pm 1$ & NS \\
\hline Sex: male & $21(51 \%)$ & $47(71 \%)$ & .042 \\
\hline Pretreatment $\mathrm{AL} T, \mathrm{U} / \mathrm{L}$ & $86 \pm 11$ & $120 \pm 17$ & .08 \\
\hline $\begin{array}{l}\text { No. with elevated pretreat } \\
\text { level }\end{array}$ & $25(61 \%)$ & $41(62 \%)$ & NS \\
\hline $\begin{array}{l}\text { Pretreatment HBV DNA, lo } \\
\text { copies } / \mathrm{mL}\end{array}$ & $8.85 \pm 0.16$ & $8.60 \pm 0.14$ & NS \\
\hline $\begin{array}{l}\text { Pretreatment histology sh } \\
\text { cirrhosis }\end{array}$ & $4(10 \%)$ & $8(12 \%)$ & NS \\
\hline $\begin{array}{l}\text { Precore } \mathrm{G}_{1896} \mathrm{~A} \text { mutation } \\
\text { Core promoter } \mathrm{A}_{1762} \mathrm{~T}, \mathrm{G}_{1}\end{array}$ & $18(44 \%)$ & $15(23 \%)$ & .041 \\
\hline mutation & $5(12 \%)$ & $33(50 \%)$ & $<.001$ \\
\hline Treatment with IFN- $\alpha$ & $31(76 \%)$ & $42(64 \%)$ & NS \\
\hline Antiviral response & $13(32 \%)$ & $9(14 \%)$ & .029 \\
\hline $\mathrm{IFN}-\alpha$ treatment & $12 / 31(39 \%)$ & $7 / 42(17 \%)$ & .034 \\
\hline No treatment & $1 / 10(10 \%)$ & $2 / 24(8 \%)$ & NS \\
\hline
\end{tabular}

Abbreviation: NS, not significant.

predictors of $\mathrm{HBeAg}$ clearance in univariate analysis (Table 3). Multivariate analysis with stepwise logistic regression identified HBV genotype B (odds ratio [OR], 1.28; 95\% confidence interval $[\mathrm{CI}], 1.06-1.42 ; P=.006)$, low pretreatment HBV-DNA level $(\mathrm{OR}, 1.10 ; 95 \% \mathrm{CI}, 1.03-1.17 ; P=$ .007 ), and elevated pretreatment ALT level (OR, 1.22; 95\% $\mathrm{CI}, 1.05-1.42 ; P=.011)$, but not IFN- $\alpha$ treatment as independent factors associated with HBeAg clearance.

Among the 75 patients who were treated with IFN- $\alpha$, low pretreatment HBV-DNA, and elevated pretreatment ALT levels were significant predictors of antiviral response in univariate analysis whereas HBV genotype B was borderline significant (Table 4). All 3 factors were

Table 3. Univariate Analysis of Factors Associated With HBeAg Clearance Among All Patients

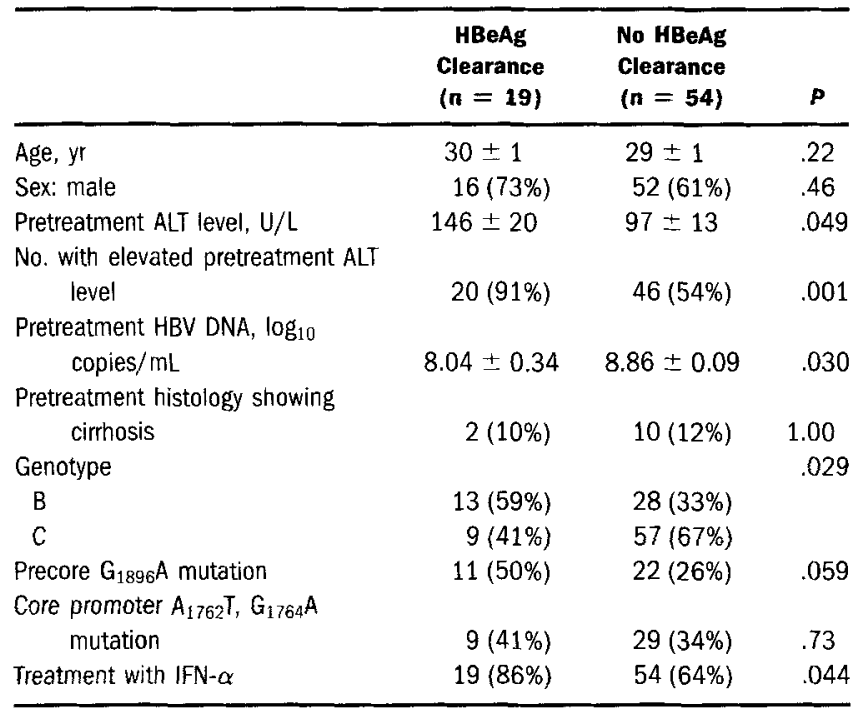

Table 4. Univariate Analysis of Factors Associated With Antiviral Response Among Patients Treated With IFN

\begin{tabular}{|c|c|c|c|}
\hline & $\begin{array}{l}\text { Responder } \\
(n=19)\end{array}$ & $\begin{array}{c}\text { Nonresponder } \\
(n=54)\end{array}$ & $\boldsymbol{P}$ \\
\hline Age, yr & $31 \pm 1$ & $29 \pm 1$ & .32 \\
\hline Sex: male & $14(74 \%)$ & $34(63 \%)$ & .58 \\
\hline Pretreatment ALT level, U/L & $151 \pm 22$ & $107 \pm 19$ & .20 \\
\hline $\begin{array}{l}\text { No. with elevated pretreatment ALT } \\
\text { level }\end{array}$ & $18(95 \%)$ & $32(59 \%)$ & .004 \\
\hline $\begin{array}{l}\text { Pretreatment HBV DNA, } \log _{10} \\
\text { copies/mL }\end{array}$ & $7.86 \pm 0.38$ & $8.82 \pm 0.12$ & .002 \\
\hline $\begin{array}{l}\text { Pretreatment histology showing } \\
\text { cirrhosis }\end{array}$ & $1(5 \%)$ & $7(13 \%)$ & .67 \\
\hline Genotype & & & \\
\hline B & $12(63 \%)$ & $19(35 \%)$ & .057 \\
\hline $\mathrm{C}$ & $7(37 \%)$ & $35(65 \%)$ & \\
\hline Precore $\mathrm{G}_{1896} \mathrm{~A}$ mutation & $10(53 \%)$ & $17(32 \%)$ & .17 \\
\hline $\begin{array}{l}\text { Core promoter } A_{1762} T, G_{1764} A \\
\text { mutation }\end{array}$ & $7(37 \%)$ & $19(35 \%)$ & .92 \\
\hline Prednisone priming & $9(48 \%)$ & $25(47 \%)$ & 1.00 \\
\hline
\end{tabular}

found to be significant predictors of antiviral response in multivariate analysis.

Patients With Elevated Pretreatment ALT Levels. Of the 66 patients with elevated pretreatment ALT levels, 20 (30\%) had $\mathrm{HBeAg}$ clearance. Antiviral response was achieved in $57 \%$ and $21 \%$ of IFN- $\alpha$-treated patients $(P=$ $.019)$, and in $25 \%$ and $8 \%$ of untreated controls $(P=.45)$ with HBV genotype $B$ and $C$, respectively (Fig. 1). Multivariate analysis showed that genotype $\mathrm{B}(\mathrm{OR}, 1.47 ; 95 \% \mathrm{CI}$, $1.18-1.82 ; P=.001)$ and low pretreatment HBV-DNA level (OR, $1.10 ; 95 \% \mathrm{CI}, 1.01-1.21 ; P=.029)$ were independent predictors of $\mathrm{HBeAg}$ clearance.

Patients With Normal Pretreatment ALT Levels. Antiviral response was uniformly low among the 41 patients with normal ALT levels. None of the 16 patients

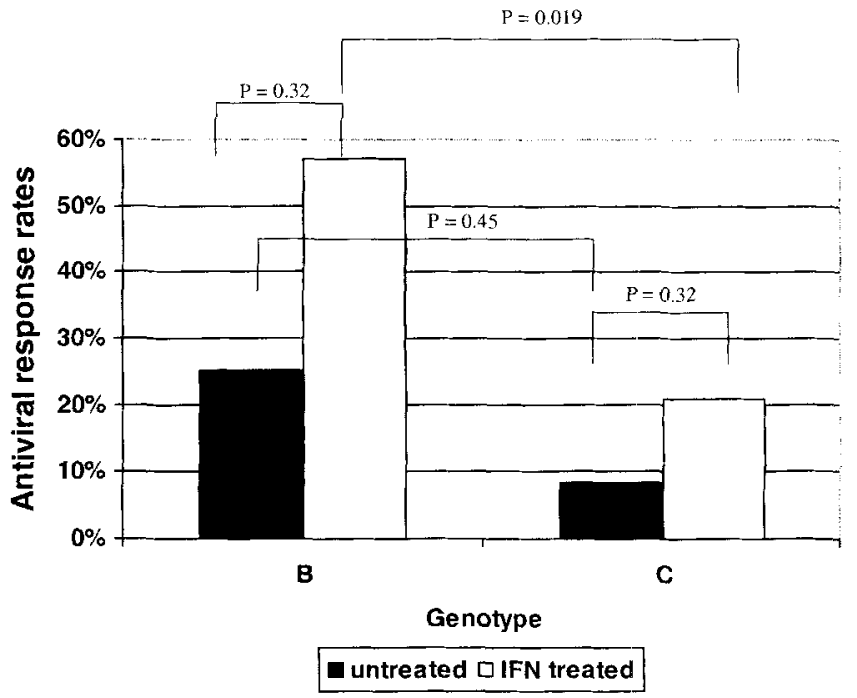

Fig. 1. Antiviral response rates in patients with elevated ALT levels in HBV genotypes B and C. $\mathbf{Q}$, untreated; $\square$, IFN treated. 
with genotype B (10 IFN- $\alpha$ treated and 6 controls), and only 2 of the 25 patients with genotype C ( 1 of 13 IFN- $\alpha$ treated and 1 of 12 controls) had an antiviral response.

\section{Discussion}

Our study confirmed a previous report from Taiwan ${ }^{8}$ that $\mathrm{HBV}$ genotype $\mathrm{B}$ is associated with a higher rate of antiviral response to IFN- $\alpha$ treatment than HBV genotype $\mathrm{C}$ among Chinese patients with $\mathrm{HBeAg}$-positive $\mathrm{CHB}$. The absence of a control group in the Taiwan study and the finding of a higher rate of spontaneous $\mathrm{HBeAg}$ seroconversion in patients with genotype $\mathrm{B},{ }^{20}$ raise questions as to whether the better response in patients with genotype $\mathrm{B}$ is attributed to the IFN- $\alpha$ treatment. In this study, IFN- $\alpha$ treatment increased the antiviral response in patients with both genotype B (39\% vs. $10 \%)$ and C $(17 \%$ vs. $8 \%)$, compared with untreated patients with the same genotype, but these differences did not reach statistical significance. The lack of statistical significance between treated patients and controls may be related to the small sample size. However, multivariate analysis with stepwise logistic regression identified HBV genotype B and not IFN- $\alpha$ treatment as an independent factor predictive of antiviral response, suggesting that the additional benefit of IFN- $\alpha$ treatment is small in patients who are likely to undergo spontaneous $\mathrm{HBeAg}$ seroconversion.

We found that the presence of precore stop codon mutation at entry was associated with a higher rate of antiviral response on univariate analysis. This is in accord with our previous analysis using a less sensitive technique-direct sequencing--to detect the precore stop codon mutation. ${ }^{11}$ Direct sequencing is unable to identify minor amounts of variant viruses in a background of wildtype sequences. ${ }^{23}$ The use of a line-probe assay increases the sensitivity of detection of precore variants, which explains the higher rate of precore stop codon mutation detected in this study (32\%) than in our previous study $(7 \%)$. Precore stop codon mutation usually is selected around the time of $\mathrm{HBeAg}$ seroconversion. Thus, $\mathrm{HBeAg}$-positive patients with detectable precore stop codon mutation may be on the verge of spontaneous $\mathrm{HBeAg}$ seroconversion. Whether IFN- $\alpha$ treatment hastened this process is unclear. Precore stop codon mutation was not an independent factor predictive of antiviral response on multivariant analysis. This may be related to the association between precore stop codon mutation and $\mathrm{HBV}$ genotype $\mathrm{B}$, with the latter being a more important factor. Alternatively, precore stop codon variant, when present as a minor species, is less predictive of imminent $\mathrm{HBeAg}$ seroconversion than when it is present as the predominant viral species. In this study, presence of the dual core promoter mutation at entry was not related to anti- viral response. Although our study is larger than previous studies, the role of core promoter mutation on response to IFN- $\alpha$ and other antiviral therapy should be further examined.

We confirmed that elevated pretreatment ALT and low pretreatment HBV-DNA levels were independent predictors of antiviral response. ${ }^{2,3}$ Elevated pretreatment ALT level also was found to be the most important predictive factor of response to lamivudine treatment among patients with $\mathrm{HBeAg}$-positive $\mathrm{CHB} .{ }^{4}$ Our results support recommendations from the American Association for the Study of Liver Diseases and the Asian Pacific Association for the Study of the Liver that patients with normal pretreatment ALT levels should not be treated because the response to currently available treatment is poor..$^{24,25}$

In summary, our study showed that in addition to low pretreatment HBV DNA and elevated pretreatment ALT levels, $\mathrm{HBV}$ genotype $\mathrm{B}$ was associated with a higher rate of antiviral response to IFN- $\alpha$ treatment in Chinese patients with $\mathrm{HBeAg}$-positive $\mathrm{CHB}$ than genotype $\mathrm{C}$. Further studies are needed to determine if $\mathrm{HBV}$ genotype also plays a role in response to IFN- $\alpha$ treatment in chronic hepatitis $B$ patients from other geographic regions where orher HBV genotypes prevail. More importantly, the role of $\mathrm{HBV}$ genotypes in response to nucleos(t)ide treatment of $\mathrm{HBeAg}$-positive as well as $\mathrm{HBeAg}$-negative $\mathrm{CHB}$ should be examined. Careful analysis of these data may lead to better selection of CHB patients for antiviral treatment and possibly development of therapeutic regimens tailored to viral genotype as in the case of hepatitis $\mathrm{C}$.

\section{References}

1. Lok AS, Heathcote EJ, Hoofnagle JH. Management of hepatitis B: 2000summary of a workshop. Gastroenterology 2001;120:1828-1853.

2. Brook MG, Karayiannis P, Thomas HC. Which patients with chronic hepatitis $B$ virus infection will respond to alpha-interferon therapy? HEPATOLOGY 1989;10:761-763.

3. Perrillo RP, Schiff ER, Davis GL, Bodenheimer HC Jr, Lindsay K, Payne J, Dienstag JL, et al. A randomized, controlled trial of interferon alfa-2b alone and after prednisolone withdrawal for the treatment of chronic hepatitis B. N Engl J Med 1990;323:295-301.

4. Perrillo RP, Lai CL, Liaw YF, Dienstag JL, Schiff ER, Schalm SW, Heathcote EJ, er al. Predictors of HBeAg loss after lamivudine treatment for chronic hepatitis B. HrPATOLOGY 2002;36:186-194.

5. Stuyver L, De Gendt S, Van Geyt C, Zoulim F, Fried M, Schinazi RF, Rossau R. A new genotype of hepatitis B virus: complete genome and phylogenetic relatedness. J Gen Virol 2000;81:67-74.

6. Chu CJ, Lok AS. Clinical significance of hepatitis B virus genotypes. HEPATOLOGY 2002;35:1274-1276.

7. Erhardt A, Heineke U, Blondin D, Gerlich WH, Adams O, Heintges T, Niederau $C$, et al. Mutations of the core promoter and response to interferon treatment in chronic replicative hepatitis B. HEPATOLOGY 2000;31: 716-725.

8. Kao JH, Wu NH, Chen PJ, Lai MY, Chen DS. Hepatitis B genotypes and the response to interferon therapy. J Hepatol 2000;33:998-1002.

9. Hunt CM, McGill JM, Allen MI, Condreay DL. Clinical relevance of hepatitis B viral mutations. HEPATOLOGY 2000;31:1034-1044. 
10. Chan HL, Hussain M, Lok AS. Different hepatitis B virus genotypes are associated with different mutations in the core promoter and precore regions during hepatitis B e antigen seroconversion. HePATOLOGY 1999;29: 976-984.

11. Lok AS, Akarca US, Greene S. Predictive value of precore hepatitis B virus mutations in spontaneous and interferon-induced hepatitis $\mathrm{B}$ e antigen clearance. Hepatology 1995;21:19-24.

12. Brunetto MR, Giarin M, Saracco G, Oliveri F, Calvo P, Capra G, Randone $A$, et al. Heparitis $B$ virus unable to secrete e antigen and response to interferon in chronic hepatitis B. Gastroenterology 1993;105:845-850.

13. Schepis F, Verucchi G, Pollicino T, Attard L, Brancatelli S, Longo G, Raimondo G. Outcome of liver disease and response to interferon treatment are not influenced by hepatitis $B$ virus core gene variability in children with chronic type $B$ hepatitis. J Hepatol 1998;26:765-770.

14. Zhang $X$, Hian $Y$, Lu Z, Gao J, Luo Z, Zhang D. Effect of multiple mutations in the core promoter and pre-core/core region of hepatitis $B$ virus genome on the response to interferon in e antigen-positive chronic hepatitis B. J Gastroenterol Hepatol 2001;16:393-398.

15. Hannoun C, Horal P, Krogsgaard $K$, Lindh $M$. Mutations in the X region and core promoter are rare and have little impact on response to interferon therapy for chronic hepatitis B. J Med Virol 2002;66:171-178.

16. Zollner B, Petersen J, Schafer P, Schroter M, Laufs R, Sterneck M, Feucht $\mathrm{HH}$. Subtype-dependent response of hepatitis B virus during the early phase of lamivudine treatment. Clin Infect Dis 2002;34:1273-1277.

17. Kao JH, Liu CJ, Chen DS. Hepatitis B viral genotypes and lamivudine resistance [Letter]. J Hepatol 2002;36:303-305.
18. Westland C, Delaney W, Ynag HL, Fry J, Brosgart C, Gibbs C, Miller M, et al. Distribution and clinical response of HBV genotypes in phase III studies of adefovir dipivoxil [Abstract]. J Hepatol 2002;36(Supp 1):105.

19. Lok A, Wu PC, Lai CL, Lau JY, Leung EK, Wong LS, Ma OC, et al. A controlled trial of interferon with or without prednisone priming for chronic hepatitis B. Gastroenterology 1992;102:2091-2097.

20. Chu CJ, Hussain M, Lok AS. Hepatitis B virus genotype B is associated with earlier $\mathrm{HBeAg}$ seroconversion compared with hepatitis $\mathrm{B}$ virus genotype C. Gastroenterology 2002;122:1756-1762.

21. Chu CJ, Hussain M, Lok A. Concordance between line probe assay and direct sequencing for determination of HBV genotype [Abstract]. HEPATOLOGY 2001;34:616A.

22. Chu CJ, Han SH, Perrillo RP, Keeffe E, Min AD, Carey W, Soldevila-Pico $\mathrm{C}$, et al. Prevalence of HBV molecular epidemiology of HBV infection in the United States [Abstract]. HePATOLOGY 2001;34:617A.

23. Pas SD, de Man RA, Fries E, Osterhaus AD, Niesters HG. The dynamics of mutations in the YMDD motif of the hepatitis $B$ virus polymerase gene during and after lamivudine treatment as determined by reverse hybridisation. J Clin Virol 2002;25:63-71.

24. Lok ASF, McMahon BJ. Chronic hepatitis B. Hepatology 2001;34 1225-1241.

25. Core working party for Asia-Pacific consensus on hepatitis B and C. Consensus statements on the prevention and management of hepatitis $B$ and hepatitis C in the Asia-Pacific region. J Gastroenterol Hepatol 2000;15: $825-841$. 